Smolarczyk A., The political life of the Ukrainian minority in the province of Polesia between 1918 and 1939, „Economics and Law”, Polszakiewicz B., Boehlke J. (ed.), Vol. 13, No. 1/2014, pp. 7-26. DOI: http://dx.doi.org/10.12775/EiP.2014.001.

\title{
THE POLITICAL LIFE OF THE UKRAINIAN MINORITY IN THE PROVINCE OF POLESIA BETWEEN 1918 AND 1939
}

\author{
SUMMARY
}

The article presents functioning of the political parties that focus the Ukrainian minority that lived in the province of Polesia in the interwar period. An enormous influence on the activity of the Ukrainian political parties had the Communist parties (KPZU, KPZB), which effectively supplanted the Ukrainian nationalist groups that acted in Polesia. From the beginning of the thirties the repressions of Polish security apparatus were so strong that almost completely inhibited the development of the Ukrainian political life.

Keywords: Ukrainian minority, political life, the province of Polesia, Communist parties, nationalist parties

JEL Classification: N44, R59

\section{INTRODUCTION}

Polesia province in the interwar period belongs to one of the least examined territories of Poland. The main reason for this situation was the difficul-

Andrzej Smolarczyk, Bialystok University of Technology, Faculty of Management, Departments Economics and Social Sciences, ul. O. Tarasiuka 2, 16-001 Kleosin, phone: +48 85746 98 29, e-mail: ondrasz@pb.edu.pl. 
ty in accessing the Belorussian and Lithuanian archives in the former Soviet Union. Till the beginning of 1990s it was impossible to research the eastern part of the Second Polish Republic because the archives were inaccessible to the researches. A breakthrough in the research was made in 1990. Opening of the Eastern archives and making them accessible to Polish researchers have given them a great opportunity to do a comprehensive research.

The most elementary source material dealing with Polesia province produced in the interwar period is situated in the State Archive of Brest in Brest, Belarus (PAOB) - Dziarżauny Archiu Breskaj Wobłasti. Supplementary documentation can be found in the Central Archives of Modern Records (AAN).

Works by W. Śleszyński ${ }^{1}$, J. Januszewska-Jurkiewicz ${ }^{2}$ and E. Kirwiel ${ }^{3}$ are the most important studies dealing with north-eastern territories of the Second Polish Republic.

General description of the ethnic policy of the Polish Authorities has been presented in the works of A. Chojnowski ${ }^{4}$ and $\mathrm{W}$. Paruch ${ }^{5}$ as well as in the publications of M. Papierzyńska-Turonek ${ }^{6}$, R. Torzecki $^{7}$, E. Mironowicz ${ }^{8}$, H. Głogowska9.

${ }^{1}$ W. Śleszyński, Bezpieczeństwo werwnętrzne w polityce państwa polskiego na ziemiach pótnocno-wschodnich II Rzeczypospolitej, PWN, Warszawa 2007.

2 J. Januszewska-Jurkiewicz, Stosunki narodowościowe na Wileńszczyżnie w latach 1920-1939, Wydawnictwo Uniwersytetu Śląskiego, Katowice 2010.

${ }_{3}$ E. Kirwiel, Kresy Pótnocno-Wschodnie Rzeczypospolitej Polskiej w latach 1918-1939. Oblicze polityczne, Wydawnictwo Uniwersytetu Marii Curie-Skłodowskiej, Lublin 2011.

${ }^{4}$ A. Chojnowski, Koncepcje polityki narodowościowej rządów polskich w latach 1921-1939, Ossolineum, Wrocław 1979.

${ }^{5}$ W. Paruch, Od konsolidacji państwowej do konsolidacji narodowej. Mniejszości narodowe w myśli politycznej obozu pitsudczykorwskiego (1926-1939), Wydawnictwo Uniwersytetu Marii Curie-Skłodowskiej, Lublin 1997.

${ }^{6}$ M. Papierzyńska-Turonek, Sprawa ukrainska w Drugiej Rzeczypospolitej 1922-1926, Wydawnictwo Literackie, Kraków 1979.

7 R. Torzecki, Kwestia ukrainska w Polsce w latach 1923-1929, Wydawnictwo Literackie, Kraków 1989.

${ }^{8}$ E. Mironowicz, Biatorus, Trio, Warszawa 1999; E. Mironowicz, Biatorusini i Ukraincy w polityce obozu pitsudczykorwskiego, Wydawnictwo Uniwersyteckie Trans Humana, Białystok 2007; E. Mironowicz, Biatorusini w polityce pitsudczyków w latach dwudziestych, „Białoruskie Zeszyty Historyczne”, Nr 23/2003; E. Mironowicz, Plany integracji ziem wschodnich II Rzeczypospolitej w polityce obozu sanacyjnego (1935-1937), „Białoruskie Zeszyty Historyczne”, Nr 18/2005; E. Mironowicz, Polityczne uwarunkowania funkcjonowania Kościota prawostawnego w Polsce w latach 1920-1939, „Białoruskie Zeszyty Historyczne”, nr 24/2005; E. Mironowicz, S. Tokć, R. Radzik, Zmiany struktury narodowościowej na pograniczu polsko-biatoruskim w XX wieku, Wydawnictwo Uniwersytetu w Białymstoku, Białystok 2005.

${ }_{9}$ H. Głogowska, Stosunki polsko-biatoruskie w XX w. Od Imperium Rosyjskiego do Unii Europejskiej, Wydawnictwo Uniwersyteckie Trans Humana, Białystok 2012. 
With regard to the issues relating to Polesia province, the already mentioned publication of W. Śleszynski and the monography of P. Cichoracki ${ }^{10}$ deserve a special mention.

The issue of national minorities was also presented in the publications of K. Gomółka ${ }^{11}, \mathrm{H}$. Chałupczak and T. Browarek ${ }^{12}$.

The functioning of the Ukrainian education and Ukrainian cultural and educational activities is discussed in the work of M. Iwanicki ${ }^{13}$, M. Syrnyk ${ }^{14}$, I. S. Zuljak ${ }^{15}$ and J. Doroszewski ${ }^{16}$.

The aim of this paper was to reconstruct the structure of the Ukrainian Political Movement in the province of Polesia between 1919 and 1939 as well as to present its party and ideological diversity.

${ }^{10}$ P. Cichoracki, Polesie nieidylliczne. Zaburzenia porzadku publicznego w wojerwództwie poleskim w latach trzydziestych XX w., Wydawnictwo LTW, Łomianki 2007; P. Cichoracki, Droga ku anatemie: Wactaw Kostek-Biernacki (1884-1957), Instytut Pamięci Narodowej, Warszawa 2009.

${ }^{11}$ K. Gomółka, Biatorusini w II RP, „Zeszyty Naukowe Politechniki Gdańskiej”. Ekonomia XXXI, Nr 495/1992; K. Gomółka, Biatoruskie partie i organizacje prorzadowe w II Rzeczypospolitej, „Białoruskie Zeszyty Historyczne”, Nr 7/1997; K. Gomółka, Między Polskq a Rosją. Biatoruś w koncepcjach polskich ugrupowań politycznych 1918-1922, Gryf, Warszawa 1994; K. Gomółka, Polityka rzqdów polskich wobec mniejszości biatoruskiej w latach 1918-1939, „Białoruskie Zeszyty Historyczne", Nr 4/1995; K. Gomółka, Polskie ugruporwania polityczne wobec kwestii biatoruskiej w latach 1918-1922, Centralny Ośrodek Metodyczny Studiów Nauk Politycznych, Warszawa 1989; K. Gomółka, Ruch biatoruski w przededniu II wojny światorwej, „Białoruskie Zeszyty Historyczne", Nr 13/ 2000; K. Gomółka, Sprawa biatoruska w koncepcjach Narodowej Demokracji w latach 1918-1922, [in:] W. Wrzesiński (ed.), Polska - Polacy - mniejszości narodowe. Polska myśl polityczna XIX i XX w., Tom VIII, Wrocław 1992.

12 H. Chałupczak, T. Browarek, Mniejszości narodowe w Polsce 1918-1995, Wydawnictwo Uniwersytetu Marii Curie-Skłodowskiej,Lublin 2000.

${ }_{13}$ M. Iwanicki, Oświata i szkolnictwo ukrainskie w Polsce w latach 1918-1939, Wyższa Szkoła Pedagogiczna, Siedlce 1975.

${ }^{14}$ M. Syrnyk, Ukraincy w Polsce 1918-1939. Oświata i szkolnictwo, Krynica Design Studio, Wrocław 1996.

15 І.С. Зуляк, Діяльність “Провіти” у Західній Україні в міжвоєнний період (1919-1939 г2.), Тернопіль 2005.

16 J. Doroszewski, Podstawy ideologiczne szkolnictwa i ich konsekwencje dla mniejszości narodowych w Polsce w latach 1918-1939, [in:] E. Walewander (ed.), Katolicka a liberalna myśl wychowawcza w Polsce, Redakcja Wydawnictw Katolickiego Uniwersytetu Lubelskiego, Lublin 2000; J. Doroszewski, Powstanie i likwidacja pierwszych szkót ukraińskich na Chetmszczyźnie i Podlasiu w 1918 roku, „Przegląd Historyczno-Oświatowy”, Nr 3-4/2000; J. Doroszewski, Praca oświatowa i kulturalna na Lubelszczyźnie w latach II Rzeczypospolitej, Wydawnictwo Lubelskie Nowe, Lublin 1995; J. Doroszewski, Rozwój życia oświatowego wśród dorostych na Zamojszczyźnie w latach 1918-1939, „Przegląd Historyczno-Oświatowy”, Nr 1-2/1999; J. Doroszewski, Ukraińskie organizacje oświatowe na Lubelszczyźnie w latach 1918-1939, „Rozprawy z dziejów oświaty" t. XXXVIII/1997. 
The basis of the scientific work was the methodology of the historical sciences. The publication has been based mainly on the source materials that have not been elaborated yet. The author of this paper has done an archival research in State Brest Province Archive in Brest, Belorussia.

\section{POLESIA PROVINCE BETWEEN 1918 AND 1939 - ADMINISTRATIVE DIVISION, ETHNIC ISSUES}

The Treaty of Riga gave Poland the western part of Polesia. The eastern part of Polesia has been assigned to the Soviet Union. During the transitional period the western lands of Polesia were administered by the Civil Board of Eastern Territories ("Zarząd Cywilny Ziem Wschodnich" - ZCZW), which divided the territory administratively into districts (in the future: the provinces) and counties. Polesia province was created out of the most of the Polish part of Polesia and consisted of the territories of the former Gubernia of Grodno, Minsk and Volyn ${ }^{17}$. The southern part of Polesia became a part of Volyn province (districts of Kostopil, Kovel, VolodymyrVolynsky). The Northern edge of Polesia became a part of Navahrudak province (the southern part of districts: baranowicki and Nesvizh). The territories that did not belong to the geographical Polesia joined the newly created Polesia province. These were: the northern and central part of the district of Brest, the western part of Kobryn district and northern part of Kosava dis$\operatorname{trict}^{18}$. The process of territorial formation of Polesia province ended in 1931, removing Sarny district and joining it to Volyn province. After 1931, Polesia province had nine districts: that of Brest, Drahichyn, Kobryn, Kosava, KaminKashyrskyi, Luninets, Pinsk, Pruzhany, Stolin. The capital city was Brest on the Bug River, situated on the western edge of the province. Because of its location Brest was not able to exercise an efficient influence on all Polesia. The role of the natural capital city was overtaken by the centrally located Pinsk ${ }^{19}$.

In 1931 Polesia province had an area of $36668 \mathrm{~km} 2$ and was inhabited by about 1132200 people $^{20}$. In terms of area it was the largest in the Sec-

17 W. Bieńkiewicz, Niektóre wiadomości o województwie poleskim, [in:] Rocznik Poleski 1927, Brześć n. Bugiem 1927, p. 29.

${ }^{18}$ J. Tomaszewski, Z dziejów Polesia 1921-1939. Zarys stosunków spoteczno-ekonomicznych, Państwowe Wydawnictwo Naukowe, Warszawa 1963, p. 10.

${ }^{19}$ A. Lewkowska, J. Lewkowski, W. Walczak, Zabytkowe cmentarze na Kresach Wschodnich Drugiej Rzeczypospolitej. Województwo Poleskie na obszarze Republiki Biatorus, Ośrodek Ochrony Zabytkowego Krajobrazu Narodowa Instytucja Kultury, Warszawa 2000, p. 27.

${ }^{20}$ GUS, Maty Rocznik Statystyczny 1937, Warszawa 1937, p. 13-15. 
ond Polish Republic but it had the smallest population. The average density of the population in the whole country was 83 people per square kilometre. The density of population in Polesia was quite uneven. Absolute numbers do not necessarily reflect the actual situation of population in Polesia. In the most densely populated districts: that of Pruzhany and Drahichyn, there were 41 inhabitants per square kilometre, while in the border district of Luninets, which was wooded and swampy, there were 19 people per square kilometre. We can assume that only $18 \%$ of Polesia province was suitable for cultivation (36\% of the area were forests, $20 \%$ were meadows, so-called 'acid' meadows and $16 \%$ was marshland) but an average rate of density population significantly increased. In the least populated district of Luninets only $8 \%$ of the area was suitable for cultivation. The rate of density population compared with agricultural land was 215-240 people per square kilometre. Indeed, Polesia was overcrowded ${ }^{21}$.

The population of Polesia province in the interwar period was not homogeneous. It was a religious, national and cultural mosaic forming a colorful borderland community. It is extremely difficult to describe this community and not easy to make generalizations about it. According to data from the general census conducted in 1921, the population of Polesia was about 749370 inhabitants, which meant that statistically there were 20.8 inhabitants per square kilometre. In the general census of 1931 it was stated there were approximately 1131939 inhabitants, i.e. there were statistically 31 inhabitants per square kilometre.

The sticking point was the question of the indigenous people of Polesia (Polishchuks) who called themselves as "the local" people ("tutejszy"). This intriguing issue has been deeply mythologized and was marked by many stereotypes. The indigenous population of Polesia was characterized by lack of a specified national self-identity but having a strong sense of identity and belonging to their own social group that was characterized by separate language and faith ${ }^{22}$. Lack of national self-identity of Polishchuks has become the cause of permanent fight of Polish, Russian, Belorussian and Ukrainian nationalisms for the national identity of this indigenous population. This fight lasted for the whole interwar period. Belorussians deemed Polishchuks as Belorussians due to the location of the greater part of Polesia in the area of historical Belarus. Ukrainians deemed them as Ukrainians because of their language. The

${ }^{21}$ F. Leszczełowski, Stosunki narodowościowe i potrzeby kulturalne na Polesiu, [in:] Polska Macierz Szkolna na Polesiu, Wydawnictwo Zarządu Głównego Polskiej Macierzy Szkolnej, Warszawa 1939, p. 14.

22 A. Lewkowska, J. Lewkowski, W. Walczak, op. cit., p. 29. 
fact is the language of Polishchuks was not a separate language. We should say it is a group of dialects of Polesia lying in the transition zone from the Ukrainian to Belrussian dialects (with the dominance of Ukrainian dialects). Ukrainian influences dominated in the areas that were located in the south of the Pripyat. To the north of Pripyat the influences of the Belorussian dialects were stronger. In the dialects of Polesia also strong influences of Polish and Russian languages could be dectected. In fact, in each village of Polesia, people talked a bit differently ${ }^{23}$. If in thinking about the struggle for influence among Polishchuks, we consider the element of national consciousness, which in Ukrainians was very strong whereas in Belorussians just woke up, we can formulate the hypothesis that among the "local" people definitely Belarusians were certainly the most dominating group ${ }^{24}$.

According to the census in 1931, the Ukrainian minority who lived in Polesia had about 53540 people, which was $4.6 \%$ of the whole residents. They lived almost entirely the district of Kamin-Kashyrskyi and partly in the districts of Brest, Kobryn, Drahichyn, Pinsk and Stolin ${ }^{25}$. Ukrainians had $4.6 \%$ of over 50 hectares landed estates. In the cities, the Ukrainians were involved in free professions, competing here with the Jews and the Poles. The Ukrainian minority, that was aware of their national identity, firmly fought for the Ukrainian school, led the political agitation among Polishchuks and was developing Ukrainian cultural life.

\section{THE ORIGINS OF THE POLITICAL ACTIVITY OF UKRAINIANS IN POLESIA}

The Ukrainian political movement was not active in the prewar Polesia. Lack of the transport connections and extremely low culture of population in Polesia did not encourage the Ukrainians to the political expansion. The situation changed after the occupation of Polesia by the Germans. The signing of the Treaty between Germans and Ukrainians (February 9, 1918), has completely changed the political relations in this region. Under the terms of this treaty, Polesia became a part of the Ukrainian People's Republic. The process of ukrainization of Polesia began and the Ukrainian National-Political Movement has developed its activity. This movement was very weak in its initial

${ }^{23}$ G. Rąkowski, Czar Polesia, Rewasz, Pruszków 2001, p. 224.

${ }^{24}$ J. Tomaszewski, op. cit., p. 25.

${ }_{25}$ Z. Urbański, Mniejszości narodowe w Polsce, Wydawnictwo „Mniejszości Narodowe”, Warszawa 1932, p. 22. 
phase. The management was in the hands of the migrant activists or a small number of local intelligence, which often have the Russian origin ${ }^{26}$.

The revival of the Polish state, the withdrawal of the Germans and later Polish-Russian and Polish-Ukrainian conflicts in Polesia stopped further development of the Ukrainian political life. Ukrainian influences survived in Brest, Kobryn, Drahichyn and, after moving the front line of the Polish-Bolshevik war to the east, continued to develop. This activity had mainly cultural character and was limited to the existence of social groups cultivating the Ukrainian folk music and dramatic arts ${ }^{27}$.

After the Peace of Riga relative stabilization contributed to the development of political life in this region. Polesia has become a place of the political struggle for Polish, Belorussian and Ukrainian parties. The following parties started their activities: the Polish Socialist Party (Polska Partia Socjalistyczna - PPS), the Polish Peasant Party "Liberation" (Polskie Stronnictwo Ludowe "Wyzwolenie" - PSL), Belorussian Association of Peasants (Białoruski Związek Włościański - BZW) and Ukrainian progenitor of the future SelSojuz, which then was not a formally organized political party yet. The main showdown between these parties took place during the pre-election campaign to the Parliament in 1922. As a result of it, the Polish Socialist Party (Polska Partia Socjalistyczna - PPS) has won four seats, the Polish Peasant Party "Liberation” (Polskie Stronnictwo Ludowe „Wyzwolenie”- PSL) has won two seats and the Block of National Minorities (Blok Mniejszości Narodowych - BMN) has won four seats. As far as these four seats go, two of them were taken by the Ukrainians: Sergiusz Chrucki and Bazyli Dmitriuk, one went to Belorussians (Fabian Jaremicz), one went to the representative of the Jewish minority ${ }^{28}$.

The election result was a huge success for the Ukrainians. It confirmed Ukraine's claim to Polesia and created the basis for the development of future propaganda activities in this area. The political activities of Ukrainian parties in 1923-1926 in Polesia province was not intense ${ }^{29}$. Sel-Sojuz had a political program, but it has not had an organized political party yet. Ukrainian political activity during this period consisted mainly of occasionally organized speeches of the Ukrainian MPs in the larger centers of the province. It should

${ }^{26}$ Archiwum Akt Nowych, Urząd Wojewódzki w Brześciu, Ruch ukraiński na Polesiu 1918-1933. Dziatalność ukraińskich stronnictw politycznych na Polesiu, sygn. 36, k. 7.

${ }^{27}$ Ibidem, k. 7-8.

${ }^{28}$ Ibidem.

29 Państwowe Archiwum Obwodu Brzeskiego w Brześciu, Wiadomości z wtasnego pasa ochrony. Kwestie narodowościowe, sygn. f. 2029, o. 2, d. 1, k. 19 v.-20. 
be noted that the MPs elected from Polesia (S. Chrucki and B. Dmitriuk) were not very active. The initiative in the region was taken over by the Communist MPs: Wojtiuk, Skrypa, Paszczuk, Prystrupa. They successfully competed with the PPS and PSL "Liberation" overbidding each other in declaring the radical and populist slogans. The Ukrainian Communist movement received the strong support from the Soviet Union ${ }^{30}$.

\section{UKRAINIAN POLITICAL MOVEMENT IN 1923-1926}

In the southern part of Polesia province the Communist Party of Western Ukraine (Komunistyczna Partia Zachodniej Ukrainy - KPZU) (which was established in 1923) was very active. This party was working illegally as an autonomous peripheral organization of Communist Party of Polish Workers (Komunistyczna Partia Robotniczej Polski - KPRP), then Polish Communist Party (Komunistyczna Partia Polski - KPP). Dividing the influences in Polesia between the two communist parties - the Communist Party of Western Belarus (Komunistyczna Partia Zachodniej Białorusi - KPZB) and KPZU that were formally part of the KPP, did not coincide with the national preferences among the population and the local activists. The principal idea of the whole communist movement was the class struggle. It was subordinated to all other goals, including the issues of national liberation struggle. In the counties under the influence of Belorussian Communists, even legal organizations that have in their names the adjective "Ukrainian" ("ukrainski") were actually controlled by members of KPZB ${ }^{31}$. Since the beginning of $1924, \mathrm{KPZB}$ began to establish their local branches in the province of Polesia. Within a few months, the area of Polesia from the northern part of the county of Brest to the county of Sarny was covered with a dense network of KPZB branches ${ }^{32}$.

During a congress of Sel-Sojuz in Chełm (August 17, 1924) the statute of party has been accepted. The Ukrainian Union of Socialist Peasant Association (Ukraińskie Zjednoczenie Socjalistyczne Związek Włościański (Sel-Sojuz)) (Sel-Sojuz) has been formally established ${ }^{33}$. At the congress the strategy of further activity of the party was presented. In September 1924 in

\footnotetext{
30 Archiwum Akt Nowych, Urząd Wojewódzki w Brześciu, op. cit., k. 9.

${ }^{31}$ W. Śleszyński, op. cit., p. 288-289.

32 The county of Sarny belonged to the province of Polesia until 1930.

${ }^{33}$ The Ukrainian Union of Socialist Peasant Association (Ukrajinśkie Socialistyczne Objednannia Selanskiyj Sojuz - Sel-Sojuz) - the group that described themselves as a class representation of Ukrainian peasants, it fought for the socialist system, the full rights of peasants and land reform.
} 
the Polesia province the party held two meetings in Drahichyn and Kobryn, where a further consolidation of the group in Polesia has been acheived. The Party has been given the character of the peasant socialist group. Sel-Sojuz was the first legal left-wing party, which got quickly dominated by the Communists $^{34}$. Revolutionary sentiments led to the expulsion of B. Dmitriuk, who decided to maintain his moderate beliefs ${ }^{35}$. In the second half of 1924 the organizational actions of Sel-Sojuz ended. Two regional committees in Kobryn and Drahichyn were founded as well as dozens of rural committees in the districts of: Brest, Kobryn, Drahichyn and Pinsk. In the fight for influence among the rural voters in the districts of Brest, Drahichyn and Kobryn the influences of PSL "Liberation" have been marginalized ${ }^{36}$.

The organisational activities of Sel-Sojuz which have been undertaken during the district conventions, met with the similar initiatives of KPZB. The relations between Sel-Sojuz and KPZB were friendly as long as KPZB accused PPS of "social-fascist tendencies and serving the bourgeois governments" and Sel-Sojuz kept the pro-Soviet sympathies. Mutual loyalty between the two groups was informed by the tactical purposes and the rules of national policy realized by the Communist Party ${ }^{37}$.

At the end of 1924 the influences of National Ukrainian Party (former: Independent Socialists) began to spread from Volyn to Polesia. The members of the party were veterans of Petlura with Włodzimierz Oskiłka as a leader, who resided in Rivne, where he edited a weekly "Dzwin" which was an organ of the party. The Ukrainian National Party was not able to have significant influences in Polesia. In 1926, W. Oskitka has been murdered, and the party broke up ${ }^{38}$.

In the second half of the 1920s, the Ukrainian National-Democratic Union (Ukrajinśkie Nacionalno-Demokratyczne Objednannia - UNDO) ${ }^{39}$ (Ukraińskie Zjednoczenie Narodowo - Demokratyczne) tried to gain the influences in Polesia province. The party did not create any formal structures, however it gained some influential supporters. UNDO activists and those supporters formed the "Proświta" association, whose offices were intensively developed in Polesia. From the point of view of the Polish security au-

34 The extremely radical factors started to have an impact during this period in Sel-Sojuz, which have sought to military solutions.

${ }^{35}$ With the passage of time, he started to pass on right-wing positions and he eventually became a supporter of UNDO.

${ }^{36}$ Archiwum Akt Nowych, Urząd Wojewódzki w Brześciu, op. cit., k. 10.

37 Ibidem.

${ }^{38}$ Ibidem.

${ }^{39}$ H. Chałupczak, T. Browarek, op. cit., p. 60. 
thorities Ukrainian Cooperative Bank in Brest (Ukraiński Bank Spółdzielczy w Brześciu) and Ukrainian Cooperative Consumers 'Unity' in Orchów (Ukraińska Spółdzielnia Spożywców "Jedność” w Orchowie) were under the influence of the group of the Union ${ }^{40}$.

The influences of Sel-Sojuz was greatly increased due to the activity of the MP Stefan Makiwka and the activists of the District Committee in Kobryn (Komitet Okręgowy w Kobryniu): Bazyli Parchocik and Dymitr Rafałowicz, who were very popular among the local people. After entering the Białoruska Włościańsko-Robotnicza Hromada (BWRH) to Polesia, Ukrainian Sel-Sojuz loyally shared with it the spheres of influence. It limited the area of its activity to counties of Kobryn and Drahichyn and the southern districts of Brest and Pinsk. But BWHR took the northern areas. On the basis of the directives of the III Congress KPP (May, 1925) the communists whose mission was to control the legal Ukrainian movement (and Belorussian one, too) in the eastern parts of Poland began to arrive to Sel-Sojuz ${ }^{41}$.

In the spring of 1926 something was happened, which according to Polish security authorities, had a significant impact on the spread of Sel-Sojuz influences in Polesia. The MP Stefan Makiwka received several wagons of grain (barley and oats) for allegedly starving people of Polesia from the Soviet Ukraine. Grains have been delivered to the address of the District Committee of the Ukrainian Union of the Socialist Union of Peasants in Kobryn on the name of the leader: D. Rafałowicz. The grain has been sold at low prices and also a large part of it has been given for free to the members and supporters of the party, the peasants, who were enrolled in the Sel-Sojuz and the local communists and the political prisoners. The project had a deep propaganda meaning. Constantly the Soviet origin of the grain has been emphasized. Some of the cash that was received from the sale of the grain was allocated for help to the political prisoners. All action was met with a lively response of people in Polesia. A large number of people started joining the Sel-Sojuz ${ }^{42}$.

In Lviv (October 10, 1925) Ukraińskie Zjednoczenie Socjalistyczne Związek Włościański and Partia Wolności Ludu merged ${ }^{43}$. A new party called Ukrainian Socialist Peasant-Workers Union (Sel-Rob) was establiehed. The groups of Sel-Sojuz, which were functioning in the Polesia province changed their names for Sel-Rob.

${ }^{40}$ W. Śleszyński, op. cit., p. 289.

${ }^{41}$ Archiwum Akt Nowych, Urząd Wojewódzki w Brześciu, op. cit., k. 11.

${ }^{42}$ F. Leszczełowski, op. cit., p. 17.

${ }^{43}$ H. Chałupczak, T. Browarek, op. cit., p. 63-64. 
Establishing the organizational structures of Sel-Rob in Polesia coincided with total loss of the influences of Polish political parties: PPS and PSL "Liberation" and the strong increase of the communist influences. In the eastern part of Polesia province, the rural committees of PPS and PSL "Liberation" got completely dominated by KPZB and partly by BWRH and were out of control of the management committees of the district. However, in the western part of Polesia province, after the secession of the MP Adolf Bona, all the local centers of PSL "Liberation" made secession with his leader and they became the organizational units of the Independent Peasants' Party (Niezależna Partia Chłopska).

In January 1927, the security apparatus liquidated many organizational units of KPZB fearing an excessive rise of the communist movement in Polesia. The most active members of the party have been sentenced to many years in prison. KPZB was forced to maintain strict conspiracy. Many activists were delegated to the legal parties: Sel-Rob- Ukrainian and BelarusianBWRH. Soon "Hromada" was closed, which let even more to expand the human potential of Sel-Rob. The split in the party has occurred on September 11, 1927. The Sel-Rob broke into the pro Bolshevik Left and right wing. The great majority of the local party circles in Polesia supported the more radical wing, submitting to the leadership of the Communists.

\section{PRE-ELECTION CAMPAIGN TO THE PARLIAMENT IN 1928}

In autumn 1927, the pre-election campaign has been launched to the legislative units. The fundamental political game was fought between the two political blocs in Polesia province. On the one hand, Non-Party Bloc for Cooperation with the Government (Bezpartyjny Blok Współpracy z RządemBBWR) has been formed, representing the Polish community, finding support in a number of economic and social organizations, declaring its political neutrality. On the other hand, the communist camp led by KPZB, grouping the former supporters of "Hromada", members and supporters of Sel-Rob Left and PPS Left ${ }^{44}$.

Sel-Rob Left was the strongest Ukrainian group in this period. The party had several district committees and several rural committees in Polesia province. It was in total dependence on KPZB. KPZB Management issued a decision to support a list of Sel-Rob Left, which effectively block grouping together the previous members of: BWRH, KPZB, Sel-Rob and PPS

\footnotetext{
${ }^{44}$ Archiwum Akt Nowych, Urząd Wojewódzki w Brześciu, op. cit., k. 13.
} 
Left. The Communists would thus protect themselves against possible cancellation of the Communist list (a list of 13 - Unity of Workers' and Peasants). The main influences of Sel-Rob Left could be observed in the western part of the province, which was electoral district No. 59 (districts of: Brest, Drahichyn, Kobryn, Kosava, Kashyrskyi and Pruzhany), exactly in the districts of: Brest, Drahichyn and Kobryn. However, the eastern districts of Polesia province has been strongly influenced by Sel-Rob Right. Especially in the district of Sarny, in which the great popularity enjoyed Chuchmai Maximus, who was the leader of the party. The Ukrainian economic and social organizations ("Proświta", banks and cooperatives) who were strongly influenced by UNDO also joined the electoral competition. On 8 September 1927, at a meeting of the delegates of these organizations Ukrainian Citizens Committee in Polesia (Ukraińskyj Hromadśkyj Committee on Polissia) has been created under the leadership of two activists of Proświta: Mikołaj Kryżanowski and Paweł Artemiuk. In its program declaration, the Committee postulated the creative work in the organizational development of civic, cultural and economic life of the Ukrainian people in Polesia on the principles of the Constitution and loyalty to the Polish State. Polish security authorities have seen in this declaration of loyalty only a tactical move to gain the favor of the authorities ${ }^{45}$.

In electoral district No. 59 two Ukrainian local lists of candidates for parliament have been reported: 1 Ukrainian National List (Ukraińska Narodowa Lista) issued by the former member of the Ukrainian National Party Aleksander Wieligodzki from Kamin-Kashyrskyi; 2 Ukrainian Narodna Hospodarcza List (Ukraińska Narodna Hospodarcza Lista), issued by the leader of Sel-Sojuz: Antoni Wasyńczuk, who did not declare his access to the Bloc of National Minorities (Blok Mniejszości Narodowych).

The results of the elections in Polesia province brought the victory of Sel-Rob Left over the other Ukrainian parties. In electoral district No. 5953 681 people voted on the list of this party, which gave it two seats in parliament. BBWR received 56984 votes and three seats. The different situation was in electoral district No. 60 (Pinsk - Luninets - Sarny - Stolin), where five groups of similar potential competed. Breakdown among the voters and a diversity of the given votes have occurred. Sel-Rob Left received 12743 votes (9\%) of which in one district of Stolin: 6788 votes (24\%) and did not get any mandate. Block of national Minorities received 13088 votes (9\%). SelRob Right had 14958 votes (10\%), of which the district of Sarny: 11779

45 Ibidem, k. 15. 
votes (26\%) - one seat. BBWR gained two seats, PPS - one, the list of Russia - one $^{46}$.

The electoral success of Sel-Rob Left contributed to the internal consolidation of its members. It was decided to reinforce the primacy of Ukrainian parties in Polesia, eliminating the other Ukrainian organizations from this area at the same time. The attack was directed against the Ukrainian economic and cultural units (the reading rooms of Proświta and cooperatives). The supporters of Sel-Rob Left were introduced into these organizations; their purpose was to take over them from the inside out and fulfill the resolutions of the Communist Party about the political activity in the legal community organizations. As early as on 24 May 1926, Sel-Rob Left was transformed into Sel-Rob Unity. The security authorities have seen the changes of the name of the party as a purely strategic move, designed to facilitate the reorganization of the party units and purify the parties from informers and provocateurs. Organizational condition of Sel-Rob Unity during this period was impressive: five regional committees (Brest, Kobryn, Drahichyn, Pinsk and Stolin) and 109 rural committees (mostly covered with units of KPZB), with over 2000 registered members ${ }^{47}$.

\section{REPRESSION OF POLISH SECURITY APPARATUS}

The strong growth the influences of Sel-Rob Unity and the strong Communist influences in this party caused a serious concern of security apparatus. The liquidation of KPZB provided to the authorities many proofs of cooperation of Sel-Rob Unity with KPZB. In the second half of 1928, many activists of Sel-Rob Unity have been sentenced to prison, because they were accused of conspiracy and espionage against the state. Huge repressions of authorities made moderate activists to withdraw from the party. The prestige of the party among the people of Polesia declined. There was much unrest among the party members. Some tension and the internal friction that have occurred between the activists of different levels were efficiently fueled by the Polish security apparatus. Provocative and destabilizing treatments were so successful that the members of the Sel-Rob Unity were in total disorganization and disintegration of most of the local offices, especially the regional committees. Field units deprived of instructors and directives from management factors have been abandoned to their fate. Within a few months

\footnotetext{
46 Ibidem, k. 16.

47 Ibidem, k. 17.
} 
there has been a process of self-destruction of Sel-Rob Unity as a large party. The most active members of the party tried to go into the reading rooms of Proświta and lead further political activity under their cover. The management which managed the reading rooms remained under the influence of UNDO and former Petlura followers realizing the intentions of Sel-Rob Unity proceeded to close the reading rooms to prevent their complete dominance of political opponents ${ }^{48}$.

In 1929, the activists of the Ukrainian Sel-Rob Unity in Polesia under the pressure of the Central Committee (KC) and KPZB, several times made an effort to rebuild the organizational structures in Polesia province. In particular, the focus was on creating a new Committee of the District of Brest but no results have been acheived. Until the time when the activists from $\mathrm{Bi}^{-}$ alski district (Lublin province), on the instructions of the Central Committee Sel-Rob in Chełm, organized the District Committee in Lepówka (District Brest) in January 1930. The creation of the party base in Brest seemed necessary. Mikołaj Cham took on the task himself. Due to the constant surveillance of security apparatus there could be no organization of KPZB in Brest. Sel-Rob had to take the brunt of "political work" in the field. The internal conflicts between the members of the party and change of the political situation in Polesia forced the members of Sel-Rob Unity to abandon those plans. Many members of the Sel-Rob Unity and management of KPZB thought that the development of the Belorussian Włościańsko-Workers' Parliamentary Club (Białoruski Włościańsko-Robotniczy Klub Poselski - BWRKP), who successfully pursued the guidelines of the Communist Party of "national liberation movement", made the mass creation of the organization of Sel-Rob Unity no longer necessary. Moreover it could be even harmful to KPZB. It stopped putting pressure on formation of local centers of the party. Despite its Ukrainity Sel-Rob Unity loyally cooperated with BWRKP. In 1930, during the elections to municipal councils in the municipalities where BWRKP issued its list of candidates, Sel-Rob Unity did not form their own lists recommending its supporters to vote on the list BWRKP and vice versa - in the municipalities in which they were submitted the lists of Sel-Rob Unity, BWRKP did not exhibit any separate lists ${ }^{49}$.

The resolving of the Parliament and escape of Mikołaj Cham behind the eastern border of the country was also found depressing to the activists of Sel-Rob Unity in Polesia, and thus inhibited its limited activities in the field.

\footnotetext{
${ }^{48}$ Ibidem, k. 18.

49 Państwowe Archiwum Obwodu Brzeskiego w Brześciu, Raport o ruchu ukrainskim na Polesiu z dnia 29 stycznia 1934 r., sygn. f. 1, o. 9, d. 46, k. 63.
} 
Many members of Sel-Rob have been accused after the celebration of the International Youth Day in September in 1930. Ukrainian activists from Galicia have been engaged to organize the election campaign to the Third Parliament, but they were unable to arrange an effective propaganda activities and Sel-Rob Unity did not play a major role in the elections. A pre-election campaign of other Ukrainian has been also unsuccessful. UNDO was supported in Polesia by some Orthodox priests and a group of Czuczmaja did not find wider acceptance, and even they had great difficulty with collecting sufficient number of signatures of voters on the candidate lists. Reasons for this poor results of Ukrainian groups should be looked for in the repression of the Polish authorities, reaching alarming rumors from the East (the period of a mass exodus from the Soviet Union to the Polish "kulaki" because of collectivization) and the results of two years of activity BBWR. During this period, Sel-Rob Unity has become completely devoided of political influence in the counties of Stolin and Drahichyn and partly that of Pinsk. However, in the districts of Brest and Kobryn its influence was limited to centers with strong communist influence and consisted mainly of young people ${ }^{50}$.

At the plenary meeting of the Sel-Rob CK Unity on 31 December 1930, and at a meeting of party leaders on 13 January 1931 one was again trying to revive the organization in Polesia. District committee of Sel-Rob Puchaczewo Unity was established in the village Puchaczewo of Brest, which brought together 60 members of the party. It developed organization of the structures of the party in district of Kobryn (it established 9 rural committees) and Kashyrskyi ( 1 rural committee $)^{51}$. Rural committees in the district of: Kobryn and Pruzhany did not survive too long. During the May 1 demonstrations, the members of the party held the communist banners and committees have been removed ${ }^{52}$.

In the Kashyrskyi district, the activity of Sel-Rob Unity has evolved differently. The activities of communist parties were relatively small in this district. In the southern part of the county there were several units of KPZU, organizationally subjected to district committees, which were located in the district of Kovel (Volyn province).

In early 1931, the Mayor of the District of Poworsk in the county of Kovel, Iłarjon Potarski established the contacts with the Communists in Stobychow (Kashyrskyi district). It began recruiting the youth people from the

${ }^{50}$ Ibidem, k. 63 v.

${ }^{51}$ Państwowe Archiwum Obwodu Brzeskiego w Brześciu, Sprawozdanie sytuacyjne nr $6 a$ za okres od 11 czerwca do 10 lipca 1932 r., k. 11.

52 Państwowe Archiwum Obwodu Brzeskiego w Brześciu, Raport.., op. cit., k. 64. 
county of Kashyrskyi. Then a secretive committee of Sel-Rob Unity in Stobychow has been set up, which came into operation next to the secret unit of KPZU. Both organizations have grown really quickly. Propagandistic action held by "doorstep". They avoided speaking outside for fear of reprisals. Little by little the units of Sel-Rob Unity and KPZU have been created in a number of neighboring villages, enormously influencing two southern district of the county. Beside the party units they formed the organization of militantly-diversionary, whose members were the former members of the spy group (existing on the border of counties: Kashyrskyi and Kovel in 19251930) and members of KPZU and Sel-Rob, who were hiding from justice. It created several branches of sabotage groups counting of 5-7 people. The parties in the district of Kashyrskyi spread the "moral subversion," telling the news about the imminent outbreak of the Polish-Soviet war; of the impending uprising in the east of the Polish Second Republic and about the joining the eastern provinces to the Soviet Union. The confusion among the local people was intensified by incompetence of police and the governor of Kashyrskyi district. The outbreak of "uprising", announced by the Sel-Rob Unity initially in May 1932, has been repeatedly postponed. It has been invoked as a result of suspected the Communists about provocation directed against the mayor of Wielki Ozyr municipality (district of Kashyrskyi) - Smolarczuk who by the sentence of the ruling party (July 19, 1932) was treacherously murdered. Inefficiency of the security authorities during the investigation allowed a number of various groups to form a strong military army that carried out several robberies and got into a confrontation with the police. Only support of the army led to the breakdown of this division into small groups. Skirmishes took place between September 1932 and January 1933. Some of fragmented groups was broken, and some of them got into the USSR ${ }^{53}$.

At the end of 1931, Sel-Rob Union had 411 organizational units in Poland, of which 193 in Eastern Galicia and 218 in the Volyn, Polesia and Lublin. The number of registered members in 1930 was 8 200, of which 3600 are young people, and 300 women. The party controlled 240 reading rooms of Proswita during this period ${ }^{54}$.

On 26 September 1932, a wide-ranging action of revision and arrests of supporters of Sel-Rob Unity has been conducted. This party was abolished and declared as illegal. Party leaders were accused of communist activities.

53 Ibidem, k. 65.

${ }^{54}$ Państwowe Archiwum Obwodu Brzeskiego w Brześciu, Struktura organizacyjna KZM, sygn. f. 92, o. 1, d. 432, k. 73. 


\section{ORGANIZATION OF UKRAINIAN NATIONALISTS}

At the turn of January and February (1929) Orhanizacija Ukrajinśkych Nacionalistiw - OUN was founded. At the beginning of its existence it has included the countries where the Ukrainian immigrants lived. It acted in conspiracy on the territory of the Second Polish Republic. It proclaimed the slogans of the armed struggle whose aim was to create an independent and united Ukraine. The party rejected any compromise with the Soviet Union and Poland ${ }^{55}$. In 1935 the new organizational unit has been appointed to the party OUN - the executive National Organization of Ukrainian Nationalists in the North-Western Ukrainian Lands. Its aim was to coordinate the activities of Polesia and Podlasie. Since the mid-thirties, it begins the attempts to extend the illegal activities of the OUN to the territory of Polesia. The secret emissaries under the excuse of the economic activity made a reconnaissance and recruited the members. In Kobryn the Kobryńska Egzekutywa Powiatowa has been created. OUN did not develop any wider activity in Polesia province. There were only sporadic contact of individual activists and the supporters in Polesia. The organization did not conduct active operations and has not carried out any significant actions around ${ }^{56}$.

\section{CONCLUSIONS}

The huge impact on the Ukrainian political organizations operating in Polesia province had the communist ideology. KPZU and KPZB had a profound impact on all Ukrainian political parties. Influence of Ukrainian nationalist organizations on the political life of Polesia was low. In the early thirties the security authorities effectively blocked the development of the Ukrainian political life.

The Ukrainian minority in the province of Polesia in the interwar period distinguished itself by a high political and social activity and also well-established national identity, especially in relation to another large Slavic minority - Belorussians. Polish security authorities have seen a great threat in communications the Ukrainian activists from the southern counties of Polesia with the Ukrainian national movement in Volhynia and Eastern Galicia. Actually

${ }_{55}$ H. Chałupczak, T. Browarek, op. cit., p. 63.

${ }^{56}$ W. Śleszyński, op. cit., p. 289-290. 
the Ukrainians from the border counties of Volhynia were in touch with the Galician Ukrainians in order to create an independent Ukrainian state.

The idea of "the Polesia wedge"("klin poleski") that has been proposed by the governor of Polesia: Stanislaw Downarowicz was intended to prevent the connection of Ukrainian and Belorussian influences in Polesia. This concept has contributed to an intense fight against the Ukrainian and Belorussian political life by the Polish authorities. The people of Polesia who were ignorant of nationally and politically, they have been polonised.

\section{BIBLIOGRAPHY}

Archiwum Akt Nowych, Urząd Wojewódzki w Brześciu, Ruch ukraiński na Polesiu 1918-1933. Dziatalność ukrainskich stronnictw politycznych na Polesiu, sygn. 36.

Bieńkiewicz W., Niektóre wiadomości o województwie poleskim, [in:] Rocznik Poleski 1927, Brześć n. Bugiem 1927.

Chałupczak H., Browarek T., Mniejszości narodowe w Polsce 1918-1995, Wydawnictwo Uniwersytetu Marii Curie-Skłodowskiej, Lublin 2000.

Chojnowski A., Koncepcje polityki narodowościowej rzadów polskich w latach 1921-1939, Ossolineum, Wrocław 1979.

Cichoracki P., Droga ku anatemie: Wactaw Kostek-Biernacki (1884-1957), Instytut Pamięci Narodowej, Warszawa 2009.

Cichoracki P., Polesie nieidylliczne. Zaburzenia porzadku publicznego w województwie poleskim w latach trzydziestych XX w., Wydawnictwo LTW, Łomianki 2007.

Doroszewski J., Podstawy ideologiczne szkolnictwa i ich konsekwencje dla mniejszości narodowych w Polsce w latach 1918-1939, [in:] E. Walewander (ed.), Katolicka a liberalna myśl wychowawcza w Polsce, Redakcja Wydawnictw Katolickiego Uniwersytetu Lubelskiego, Lublin 2000.

Doroszewski J., Powstanie i likwidacja pierwszych szkót ukraińskich na Chetmszczyźnie i Podlasiu w 1918 roku, „Przegląd Historyczno-Oświatowy”, Nr 3-4/2000.

Doroszewski J., Praca oświatowa i kulturalna na Lubelszczyźnie w latach II Rzeczypospolitej, Wydawnictwo Lubelskie Nowe, Lublin 1995.

Doroszewski J., Rozwoój życia oświatowego wśród dorostych na Zamojszczyźnie w latach 1918-1939, „Przegląd Historyczno-Oświatowy”, Nr 1-2/1999.

Doroszewski J., Ukraińskie organizacje oświatowe na Lubelszczyźnie w latach 1918-1939, „Rozprawy z dziejów oświaty” t. XXXVIII/1997.

Głogowska H., Stosunki polsko-biatoruskie w XX w. Od Imperium Rosyjskiego do Unii Europejskiej, Wydawnictwo Uniwersyteckie Trans Humana, Białystok 2012.

Gomółka K., Biatorusini w II RP, „Zeszyty Naukowe Politechniki Gdańskiej”. Ekonomia XXXI, Nr 495/1992.

Gomółka K., Biatoruskie partie i organizacje prorzadowe w II Rzeczypospolitej, „Białoruskie Zeszyty Historyczne", Nr 7/1997. 
Gomółka K., Między Polskq a Rosją. Biatorus w koncepcjach polskich ugruporwań politycznych 1918-1922, Gryf, Warszawa 1994.

Gomółka K., Polityka rządów polskich wobec mniejszości biatoruskiej w latach 1918-1939, „Białoruskie Zeszyty Historyczne”, Nr 4/1995.

Gomółka K., Polskie ugrupowania polityczne wobec kwestii biatoruskiej w latach 1918-1922, Centralny Ośrodek Metodyczny Studiów Nauk Politycznych, Warszawa 1989.

Gomółka K., Ruch biatoruski w przededniu II wojny światowej, „Białoruskie Zeszyty Historyczne", Nr 13/ 2000.

Gomółka K., Sprawa biatoruska w koncepcjach Narodowej Demokracji w latach 1918-1922, [in:] W. Wrzesiński (ed.), Polska - Polacy - mniejszości narodowe. Polska myśl polityczna XIX i XX w., Tom VIII, Wrocław 1992.

GUS, Maty Rocznik Statystyczny 1937, Warszawa 1937.Iwanicki M., Oświata i szkolnictwo ukrainskie w Polsce w latach 1918-1939, Wyższa Szkoła Pedagogiczna, Siedlce 1975.

Januszewska-Jurkiewicz J., Stosunki narodowościowe na Wileńszczyżnie w latach 1920-1939, Wydawnictwo Uniwersytetu Śląkiego, Katowice 2010.

Kirwiel E., Kresy Pótnocno-Wschodnie Rzeczypospolitej Polskiej w latach 1918-1939. Oblicze polityczne, Wydawnictwo Uniwersytetu Marii Curie-Skłodowskiej, Lublin 2011.

Leszczełowski F., Stosunki narodowościowe i potrzeby kulturalne na Polesiu, [in:] Polska Macierz Szkolna na Polesiu, Wydawnictwo Zarządu Głównego Polskiej Macierzy Szkolnej, Warszawa 1939.

Lewkowska A., Lewkowski J., Walczak W., Zabytkowe cmentarze na Kresach Wschodnich Drugiej Rzeczypospolitej. Wojerwództwo Poleskie na obszarze Republiki Biatorus, Ośrodek Ochrony Zabytkowego Krajobrazu Narodowa Instytucja Kultury, Warszawa 2000.

Mironowicz E., Biatorusini i Ukraincy w polityce obozu pitsudczykorwskiego, Wydawnictwo Uniwersyteckie Trans Humana, Białystok 2007.

Mironowicz E., Biatorusini w polityce pitsudczyków w latach dwudziestych, „Białoruskie Zeszyty Historyczne", Nr 23/2003.

Mironowicz E., Biatorus, Trio, Warszawa 1999.

Mironowicz E., Plany integracji ziem wschodnich II Rzeczypospolitej w polityce obozu sanacyjnego (1935-1937), „Białoruskie Zeszyty Historyczne”, Nr 18/2005.

Mironowicz E., Polityczne uwarunkowania funkcjonowania Kościota prawostawnego w Polsce w latach 1920-1939, „Białoruskie Zeszyty Historyczne”, nr 24/2005.

Mironowicz E., Tokć S., Radzik R., Zmiany struktury narodowościowej na pograniczu polsko-biatoruskim w XX wieku, Wydawnictwo Uniwersytetu w Białymstoku, Białystok 2005.

Państwowe Archiwum Obwodu Brzeskiego w Brześciu, Raport o ruchu ukraińskim na Polesiu z dnia 29 stycznia 1934 r., sygn. f. 1.

Państwowe Archiwum Obwodu Brzeskiego w Brześciu, Sprawozdanie sytuacyjne nr $6 a$ za okres od 11 czerwca do 10 lipca 1932 r., k. 11. 
Państwowe Archiwum Obwodu Brzeskiego w Brześciu, Struktura organizacyjna KZM, sygn. f. 92.

Państwowe Archiwum Obwodu Brzeskiego w Brześciu, Wiadomości z wtasnego pasa ochrony. Kwestie narodowościowe, sygn. f. 2029.

Papierzyńska-Turonek M., Sprawa ukraińska w Drugiej Rzeczypospolitej 1922-1926, Wydawnictwo Literackie, Kraków 1979.

Paruch W., Od konsolidacji państwowej do konsolidacji narodowej. Mniejszości narodowe w mysli politycznej obozu pitsudczykowskiego (1926-1939), Wydawnictwo Uniwersytetu Marii Curie-Skłodowskiej, Lublin 1997.

Rąkowski G., Czar Polesia, Rewasz, Pruszków 2001.

Syrnyk M., Ukraińcy w Polsce 1918-1939. Oświata i szkolnictwo, Krynica Design Studio, Wrocław 1996.

Śleszyński W., Bezpieczeństwo werwnętrzne w polityce państwa polskiego na ziemiach pótnocno-wschodnich II Rzeczypospolitej, PWN, Warszawa 2007.

Tomaszewski J., Z dziejów Polesia 1921-1939. Zarys stosunków spoteczno-ekonomicznych, Państwowe Wydawnictwo Naukowe, Warszawa 1963.

Torzecki R., Kwestia ukrainska w Polsce w latach 1923-1929, Wydawnictwo Literackie, Kraków 1989.

Urbański Z., Mniejszości narodowe w Polsce, Wydawnictwo „Mniejszości Narodowe”, Warszawa 1932.

Зуляк І.С., Діяльність “Провіти” у Західній Украӥні в міжвоєнний період (1919-1939 г2.), Тернопіль 2005. 